\title{
Genetic marker
}

National Cancer Institute ( $\mathrm{NCl})$

\section{Source}

National Cancer Institute (NCI). Genetic marker.

An identifiable segment of DNA (e.g., Single Nucleotide Polymorphism [SNP], Restriction Fragment Length Polymorphism [RFLP], Variable Number of T andem Repeats [VNTR], microsatellite) with enough variation between individuals that its inheritance and coinheritance with alleles of a given gene can be traced; used in linkage analysis. 